\title{
Factors Affecting the Survival Rate of Patients with Pulmonary Thromboembolism
}

\author{
Pulmoner Tromboembolili Hastalarda Sağkalımı Etkileyen Faktörlerin Belirlenmesi
}

\author{
(D) Hakan ÇELIKHISAR ${ }^{1}$, (D) Gülay ILLKHAN DAŞDEMIR ${ }^{2}$ \\ 1 Eşrefpaşa Hospital, Clinic of Chest Diseases, izmir, Turkey \\ 2Tire State Hospital, Clinic of Chest Diseases, Izmir, Turkey
}

\begin{abstract}
Aim: It is aimed to investigate the factors affecting the survival rate and complications that may arise throughout the treatment process from admission to the end of the 6-month period after discharge, the inpatient treatment of individuals with pulmonary thromboembolism, by monitoring these patients.
\end{abstract}

Materials and Methods: The study included adult patients who were followed up in the pulmonology clinic between 01.01.2017 and 01.12.2019 and who had at least segmental thrombus on computed tomography pulmonary angiography.

Results: The mean age of 210 patients enrolled into the study was $71.27 \pm 13.26$ years and $55(26 \%)$ of these patients were male and 155 (74\%) of them were female. Pulse rate, Modified Geneva and Wells scores, pulmonary embolism severity index (PESI) and simplified PESI scores of the nonsurvivors were higher than in the patients who survived. In non-survivors, both red cell distribution width (RDW) and mean corpuscular volume on day 1 and 5, as well as the level of hematocrits were lower. Non-survivors had higher number of platelets but lower levels of total protein and albumin in blood on days 1 and 5 . High alkaline phosphatase (ALP), total bilirubin and C-reactive protein (CRP) values on the $1^{\text {st }}$ day were found to be associated with the mortality rate on the $5^{\text {th }}$ day.

Conclusion: In our study, high PESI scores; low levels of hemoglobin, total protein, albumin as checked on day 1 and day 5; high RDW levels, high $A L P ; W B C, C R P$ and total bilirubin checked on day 5 remaining high were determined to be associated with mortality.

Keywords: Modified Geneva score, mortality, pulmonary thromboembolism, Wells score

ÖZ

Amaç: Bu çalışmada pulmoner tromboembolizmi olan bireylerin yatarak tedavisi, taburcu olduktan sonraki 6 aylık dönemin sonuna kadar olan tedavi süreci boyunca ortaya çıkabilecek komplikasyonlar ve sağkalım oranını etkileyen faktörlerin araştırılması amaçlanmaktadır.

Gereç ve Yöntem: Çalışmaya 01.01.2017-01.12.2019 tarihleri arasında göğüs hastalıkları kliniğinde izlenen ve bilgisayarlı tomografi pulmoner anjiyografisinde en az segmental seviyede trombüs saptanan yetişkin hastalar dahil edildi.

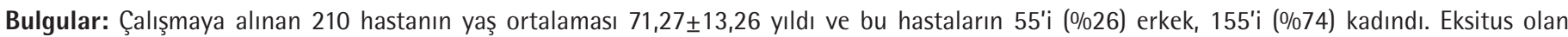
hastaların nabız hızı, Modifiye Cenevre ve Wells skorları, pulmoner emboli şiddet indeksi (PESI) ve basitleştirilmiş PESI skorları hayatta kalan hastalarınkinden daha yüksekti. Hayatını kaybeden hastalarda 1. ve 5. günlerde hem kırmızı hücre dağılım genişliği (RDW) hem de ortalama korpüsküler hacim ve hematokrit seviyeleri daha düşüktü. Hayatını kaybeden hastalar, 1. ve 5. günlerde daha yüksek sayıda trombosit ancak kanda daha düşük total protein ve albümin seviyelerine sahiplerdi. Birinci günde yüksek olan alkalen fosfataz (ALP), total bilirubin ve C-reaktif protein (CRP) değerlerinin, 5. günde olan ölüm oranı ile ilişkili olduğu saptandı.

Sonuç: Çalışmamızda yüksek PESI skorları 1. gün ve 5. günde düşük seviyelerde izlenen hemoglobin, total protein ve albüminle ilişkiliyken, yüksek seviyelerde izlenen RDW ve ALP ile ilişkiliydi. Beşinci günde yüksek olan beyaz kan hücresi, CRP ve total bilirubinin mortalite ile ilişkili olduğu belirlendi.

Anahtar Kelimeler: Modifiye Cenevre skoru, mortalite, pulmoner tromboembolizm, Wells skoru

Address for Correspondence: Hakan ÇELiKHISAR MD, Eşrefpaşa Hospital, Clinic of Chest Diseases, İzmir, Turkey

Phone: +90 2322938000 E-posta: hcelikhisar@gmail.com ORCID ID: orcid.org/0000-0002-0109-3208

Received: 19.02.2021 Accepted: 27.07.2021

๑Copyright 2021 by the Tekirdağ Namık Kemal University Faculty of Medicine / Namık Kemal Medical Journal published by Galenos Publishing House. 


\section{INTRODUCTION}

Pulmonary thromboembolism (PTE) is a treatable disease with high mortality and morbidity rates, whose diagnosis can sometimes be difficult. Annual incidence is $1 / 1000$ and it increases with age ${ }^{1,2}$. It should be known that common symptoms and physical examination findings such as dyspnea, tachypnea, tachycardia and chest pain in patients with pulmonary embolism are not unique to this disease. Clinical findings can range from an asymptomatic picture to sudden death as a result of a massive attack. Clinical diagnosis is much more difficult and unreliable in trauma or intensive care patients. Sudden onset of dyspnea and tachypnea are the most common symptoms and signs in patients with no previous cardiopulmonary problem in pulmonary embolism. Pleuritic pain with dyspnea and tachypnea is present in more than half of the cases. Hemoptysis is seen in less than $10 \%$ of cases. Clinical symptoms and findings may vary depending on the size, number (single/multiple) of the embolism, its location, the development of an infarction, the resolution rate, whether it is recurrent, the age of the patient and the reserve of cardiopulmonary functions ${ }^{2,3}$. Approximately $10 \%$ of patients undergoing deep vein thrombosis (DVT) develop PTE afterwards and nearly $10 \%$ of these patients lose their lives. Death rates within the first 3 months following the acute incident were determined as $15 \%$ in the prospective study on PTE diagnosis (Prospective Investigation of Pulmonary Embolism Diagnosis) and $17.5 \%$ in the study on international collection of PTE records (International Cooperative Pulmonary Embolism Registry $)^{3,4}$. PTE is responsible for $5-15 \%$ of all hospital deaths. Approximately $2 / 3$ of the patients undergoing or experiencing PTE are not accurately diagnosed and the mortality rates of these patients reach $30 \%$. When PTE is accurately diagnosed and the proper treatment is administered, this rate can decrease to as low as $3 \% 0^{3}$. While hospital mortality increases up to $30 \%$ due to undiagnosed PTE, hospital mortality decreases to around $8 \%$ in diagnosed cases ${ }^{4}$.

In this study, it is aimed to investigate the factors affecting the survival rate and complications that may arise throughout the treatment process from admission to the end of the 6-month period after discharge, the inpatient treatment of individuals with PTE.

\section{MATERIALS AND METHODS}

The study was carried out with adult patients being followed up with a diagnosis of pulmonary embolism in two separate pulmonology clinics. A total of 210 patients, including 55 males and 155 females, who had at least segmental thrombus in the pulmonary artery on computed tomography (CT) pulmonary angiography between 01.01.2017 and 01.12.2019 were included in the study.
The study was planned as a retrospective study and the inclusion criteria were the confirmation of the diagnosis with CT angiography, being hospitalized for at least 7 days and surviving this period, having undergone echocardiography (ECHO) and venous Doppler ultrasonography (USG) for DVT, having been reached by phone on the 6-month follow-up and completing outpatient clinic visits. Patients who died within the first 7 days of admission, pregnant women, patients whose follow-ups/analyses in the database were not complete, patients who did not visit the clinic after discharge, and patients on whom CT angiography was not performed due to high levels of creatinine were excluded.

In this period, a total of 290 patients were admitted to the service with PTE diagnosis. Fifteen patients on whom CT angiography was not performed for various reasons, 15 patients, whose $\mathrm{ECHO}$ data on admission were inaccessible, 10 patients who died within the first 7 days of admission, 25 patients whose day 1 and 7 laboratory findings were incomplete, and 15 patients who did not attend the follow-up visits and were unavailable when called by phone were not included in the study. The study was conducted with 210 patients who fulfilled all of the criteria (Figure 1).

The demographic characteristics of the cases (age, sex, body mass index, smoking history), comorbidities (chronic obstructive pulmonary disease, bronchiectasis, immunosuppression, diabetes mellitus, hypertension, coronary arterial disease, congestive heart failure, cerebrovascular accident, chronic renal failure, malignancy), risk factors (recent surgical, travel history, obesity, use of oral contraceptives, immobility), duration of admission, costs and mortalities were recorded. Respiratory rate (RR), arterial blood pressure, body temperature, heart rate, consciousness, and \% saturation $\mathrm{O}_{2}$ values obtained from the

Patients admitted to the clinic with the diagnosis of pulmonary embolism $(n=290)$

Exclusion criteria from the study;

- Patients who cannot undergo computed tomography angiography for various reasons $(n=15)$

- Patients whose echocardiography data are not available $(n=15)$

- Patients who died within the first 7 days $(n=10)$

- Day 1 and day 7 Those who lack laboratory data $(n=25)$

- Those who do not come for control and cannot be reached by phone $(n=15)$

$(n=80)$

Patients who meet the inclusion criteria $(n=210)$

Figure 1. Flowchart of study 
findings of the physical examination carried out at admission were included in the data. For cases, on whom $A B G$ analyses were performed, $\mathrm{PO}_{2}, \mathrm{pCO}_{2}, \%$ saturation $\mathrm{O}_{2}$ value and $\mathrm{pH}$ results were noted. The findings of the ECHO performed at the emergency unit and on day 7, as well as the results of bilateral lower extremity venous Doppler USG, were noted. \% Saturation $\mathrm{O}_{2}$ levels measured on days 1-6 in room atmosphere with pulse oximetry were recorded. Hemogram, coagulation, troponin, T, D-dimer, C-reactive protein (CRP), sedimentation, fibrinogen and overall biochemistry parameters at the time of arrival to emergency unit and outpatient clinic and on day 1 and 5 of admission were noted. Posteroanterior chest radiography and thorax computerized tomography findings at the time of arrival were noted. Wells and Geneva clinical probability scores and Wells bleeding risk scores, pulmonary embolism severity index (PESI) and simplified PESI (sPESI) scores measured within the first 24 hours of admission were recorded. The patients were called on the phone at Month 6 for obtaining information and were monitored with outpatient clinic follow up visits. The study was approved by the Bezmialem Vakıf University NonInvasive Ethics Committee with the decision number: 03/20, date: 05.02.2020, and all patients participating in the study filled the informed consent form. Moreover, academic study permission was obtained. The work described was carried out in accordance with the Code of Ethics of the World Medical Association (Declaration of Helsinki).

\section{Statistical Analysis}

Statistical Package for the Social Sciences 22 statistics software was used for statistical analysis. For the assessment of data, continuous variables were indicated as mean \pm standard deviation and categorical variables were indicated in \%. For comparing the two groups, Student's t-test or Mann-Whitney $\mathrm{U}$ tests were used. The correlations between the variables were studied using the Pearson or Spearman's correlation analysis. For the comparison of categorical variables, the chi-square testing was utilized. $\mathrm{P}<0.05$ value was regarded as statistically significant.

\section{RESULTS}

A total of 210 patients were enrolled into the study. The mean age of the patients was $71.27 \pm 13.26$ years. The demographical characteristics, comorbidities and risk factors of patients are shown in Table 1. When the correlation of vital signs with mortality at the time of admission was evaluated, only a significant correlation was found between high average heart rate and mortality ( $p=0.041)$. No statistically significant correlation was observed between the symptoms of the patients at the time of admission and mortality. Although the cost of admission was significantly higher for non-survivors than for the survivors, it was observed that this difference was not statistically significant $(p=0.270)$.

The average modified Geneva scores and Wells PTE clinical prediction scores were higher in non-survivors; however, this difference was not statistically significant. The correlation of PESI and SPESI scores of patients, as calculated in the emergency unit, and mortality were studied. PESI score was $109.90 \pm 34.93$ on average for non-survivors and $96.59 \pm 29.78$ for survivors, and it was observed to be higher in non-survivors. However, the difference between non-survivors and survivors in terms of PESI scores was not statistically significant $(p=0.139)$.

\begin{tabular}{|c|c|}
\hline Sex patients & (n) $\%$ \\
\hline Male & $55(26.19)$ \\
\hline Female & $155(73.80)$ \\
\hline \multicolumn{2}{|l|}{ Comorbidities } \\
\hline Diabetes mellitus & $36(17.14)$ \\
\hline Cerebrovascular accident & $24(11.42)$ \\
\hline Hypertension & $144(68.57)$ \\
\hline Coronary arterial disease & $43(20.47)$ \\
\hline Congestive heart failure & $24(11.42)$ \\
\hline Malignancy & $34(16.19)$ \\
\hline Liver diseases & 17 (8.09) \\
\hline Immune suppression & $19(09.04)$ \\
\hline \multicolumn{2}{|l|}{ Risk factors } \\
\hline Recent surgery & $43(20.47)$ \\
\hline Travel history & $19(9.04)$ \\
\hline Obesity & $60(28.57)$ \\
\hline Oral contraceptive use & $48(22.87)$ \\
\hline Major surgery & $43(20.47)$ \\
\hline Immobility & $84(40.00)$ \\
\hline Other & $108(51.42)$ \\
\hline
\end{tabular}
Table 2. Correlation of mortality with PESI and sPESI scores

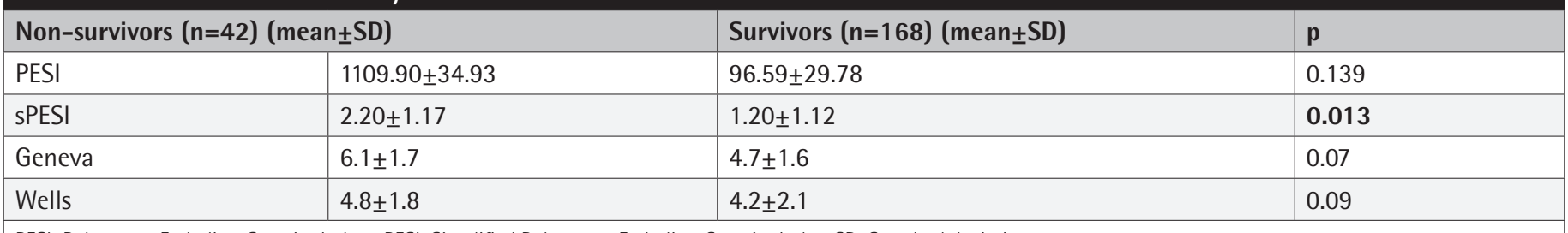

PESI: Pulmonary Embolism Severity Index, sPESI: Simplified Pulmonary Embolism Severity Index, SD: Standard deviation 
sPESI score was $2.20 \pm 1.17$ on average for non-survivors and $1.20 \pm 1.12$ for survivors, and this difference was found to be statistically significant $(p=0.013)$ (Table 2$)$.

When the correlation of the arterial blood gas ( $A B G)$ parameters at admission and mortality were studied, no statistically significant difference was observed between non-survivors and survivors.

Average WBC on day 1 was lower in non-survivors, and average WBC on day 5 was significantly higher in non-survivors and was found to be correlated with mortality $(p=0.602$ and $p=0.039$, respectively). Average platelet count on days 1 and 5 were higher in non-survivors; however, this difference was not found to be statistically significant ( $p=0.449$ and $p=0.729$, respectively). Average levels of hemoglobin on days 1 and 5 were lower in non-survivors and this was determined to be correlated with mortality ( $p=0.002$ and $p=0.008$, respectively). Average MCV on days 1 and 5 and hematocrit levels on days 1 and 5 were found to be lower in non-survivors; however, this was not significantly correlated with mortality $(p=0.289$, $p=0.071, p=0.060$ and $p=0.141$, respectively). Average levels of red cell distribution width (RDW) on days 1 and 5 were higher

Table 3. Correlation of day 1 and $\mathbf{5}$ hemogram parameters with mortality

\begin{tabular}{|c|c|c|c|}
\hline & Non-survivors $(n=42)\left(\right.$ mean $\left._{ \pm} S D\right)$ & Survivors $(n=168)\left(\right.$ mean $_{ \pm}$SD) & $\mathbf{p}^{*}$ \\
\hline WBC-1 (hc/uL) & $8520 \pm 3048$ & $9188 \pm 3418$ & 0.586 \\
\hline WBC-5 (hc/uL) & $8105 \pm 3896$ & $5874 \pm 2824$ & 0.041 \\
\hline PLT-5 (hc/uL) & $253900 \pm 107365$ & $243300 \pm 81682$ & 0.734 \\
\hline $\mathrm{Hb}-1$ (g/dl) & $10.89 \pm 1.91$ & $12.85 \pm 1.51$ & 0.003 \\
\hline MCV-5 (fl) & $81.71 \pm 5.18$ & $85.87 \pm 5.64$ & 0.071 \\
\hline HCT-1 & $35.12 \pm 5.94$ & $39.04 \pm 4.28$ & 0.059 \\
\hline HCT-5 & $32.93 \pm 3.41$ & $35.74 \pm 4.34$ & 0.143 \\
\hline RDW-1 (\%) & $14.96 \pm 2.85$ & $12.18 \pm 1.23$ & 0.021 \\
\hline
\end{tabular}

Table 4. The comparison of the parameters obtained in repeated tests in died and surviving patient groups

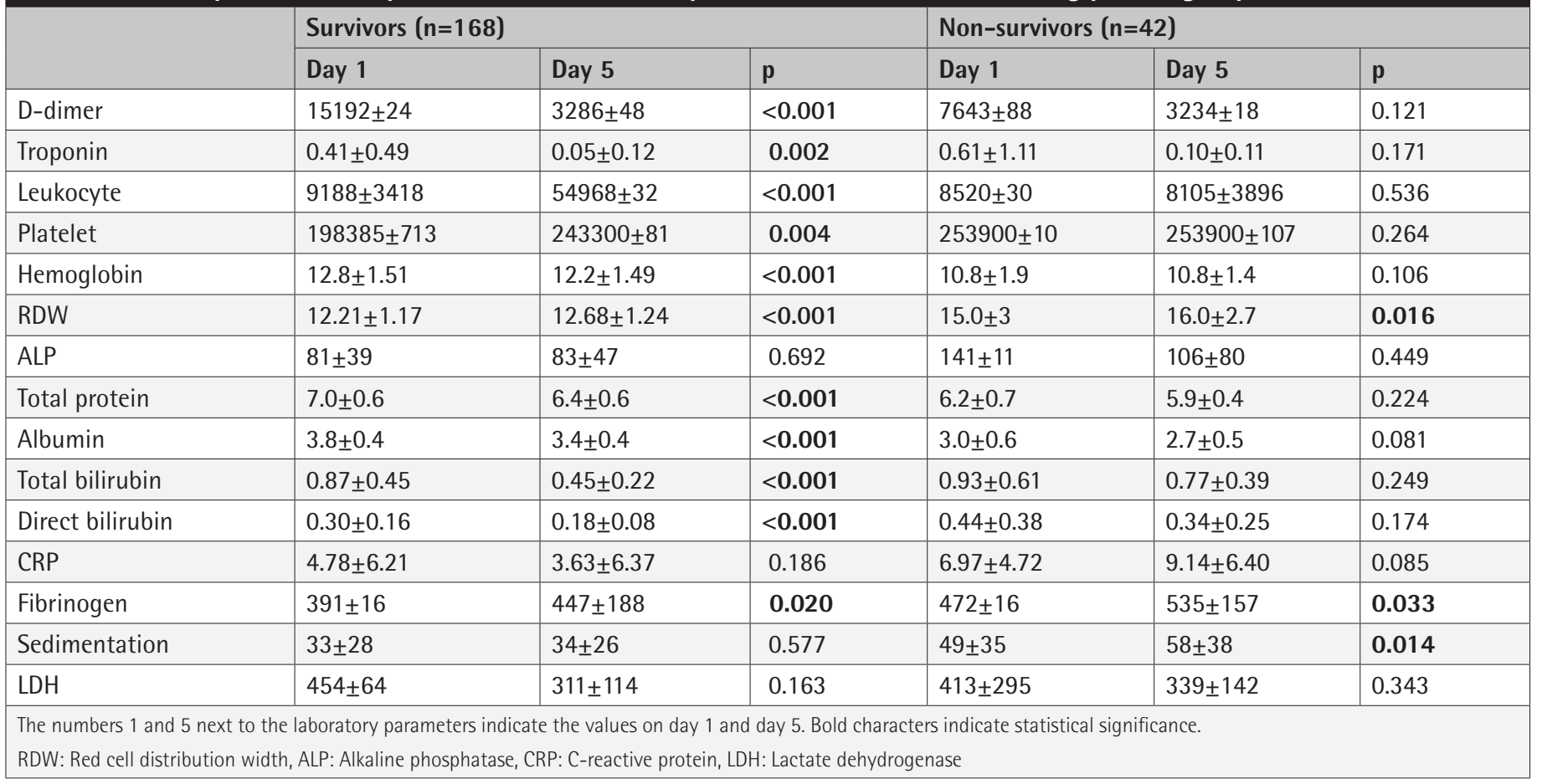


in non-survivors and this was determined to be correlated with mortality ( $p=0.003$ and $p=0.008$, respectively) (Table 3 ). The comparison of day 1 and day 5 laboratory parameters of non-survivors and survivors are shown in Table 4.

As measured on day 1 and day 5, average levels of total protein $(p=0.001$ and $p=0.002$, respectively) and albumin $(p=0.041$ and $p=0.001$, respectively) were found to be lower in non-survivors, pointing to a correlation with mortality. Average alkaline phosphatase levels on both day 1 and day 5 were higher in non-survivors; however, only the difference on day 1 was found to be correlated with mortality $(p=0.008$ and $p=0.251$, respectively). As measured on day 1 and day 5 , average total bilirubin ( $p=0.761$ and $p=0.001$, respectively) and direct bilirubin ( $p=0.259$ and $p=0.081$, respectively) were higher in non-survivors; however, only the difference in average total bilirubin on day 5 was determined to be correlated with mortality. As measured at admission (day 1), average levels of glucose, urea, creatinine, sodium, chlorine and uric acid were higher in non-survivors, and average levels of potassium, phosphorus, magnesium, alanine aminotransferase (ALT), aspartate aminotransferase (AST) and lactate dehydrogenase were lower, but these were not found to be correlated with mortality (Table 5).
Average CRP levels of patients on both day 1 and day 5 were higher in non-survivors, and the difference on day 5 was found to be correlated with mortality $(p=0.234$ and $p=0.018$, respectively). Additionally, average sedimentation, fibrinogen and troponin 1 levels on days 1 and 5 were higher, and d-dimer levels were lower in non-survivors, but no significant correlation with mortality was detected (Table 6).

4 out of 21 patients (19\%) with DVT in at least one extremity died and this was not found to be statistically correlated with mortality.

The correlation between certain ECHO parameters and mortality was examined. Two out of 4 patients (50\%), whose ejection fraction was low, 2 out of 10 patients (20\%) with large right spaces with no concomitant D-septum, and 2 out of 15 patients with D-septum died. No statistical correlation with mortality was observed in these results.

In our study, no complications such as bleeding due to the treatment used, medication side effects etc. were observed both during the inpatient treatment period and during the 6-month follow-up period.

Table 5 . Correlation of mortality with biochemical parameters on day $\mathbf{1}$ and $\mathbf{5}$

\begin{tabular}{|c|c|c|c|}
\hline & Non-survivors $(n=42)($ mean \pm SD) & Survivors $(n=168)($ mean \pm SD) & $\mathbf{p}^{*}$ \\
\hline Total protein-1 (g/dL) & $6.21 \pm 0.72$ & $7.11 \pm 0.59$ & 0.001 \\
\hline Total protein-5 (g/dL) & $5.89 \pm 0.41$ & $6.39 \pm 0.71$ & 0.003 \\
\hline Albumin-5 (g/dL) & $2.69 \pm 0.49$ & $3.39 \pm 0.38$ & $<0.001$ \\
\hline ALP-1 (U/L) & $139.25 \pm 121.13$ & $79.63 \pm 40.24$ & 0.009 \\
\hline Total bilirubin-5 (mg/dL) & $0.81 \pm 0.41$ & $0.51 \pm 0.18$ & 0.003 \\
\hline Direct bilirubin-1 (mg/dL) & $0.39 \pm 0.42$ & $0.31 \pm 0.21$ & 0.261 \\
\hline Direct bilirubin-5 (mg/dL) & $0.36 \pm 0.19$ & $0.19 \pm 0.11$ & 0.076 \\
\hline Urea $(\mathrm{mg} / \mathrm{dL})$ & $61.18 \pm 29.83$ & $51.87 \pm 19.84$ & 0.468 \\
\hline $\mathrm{CL}(\mathrm{mg} / \mathrm{dL})$ & $105.10 \pm 6.44$ & $104.64 \pm 16.47$ & 0.876 \\
\hline$P(\mathrm{mg} / \mathrm{dL})$ & $3.29 \pm 0.81$ & $3.51 \pm 0.79$ & 0.704 \\
\hline $\mathrm{Mg}(\mathrm{mg} / \mathrm{dL})$ & $1.89 \pm 0.32$ & $1.94 \pm 0.28$ & 0.889 \\
\hline $\operatorname{ALT}(\mathrm{U} / \mathrm{L})$ & $28.30 \pm 28.60$ & $49.20 \pm 158.50$ & 0.643 \\
\hline AST (U/L) & $40.70 \pm 41.30$ & $92.50 \pm 374.40$ & 0.701 \\
\hline Uric acid (mg/dL) & $7.4 \pm 4.12$ & $6.12 \pm 3.11$ & 0.204 \\
\hline $\mathrm{CK}(\mathrm{U} / \mathrm{L})$ & $78.00 \pm 89.76$ & $106.32 \pm 172.68$ & 0.654 \\
\hline LDH (U/L) & $422 \pm 301$ & $461 \pm 638$ & 0.914 \\
\hline
\end{tabular}




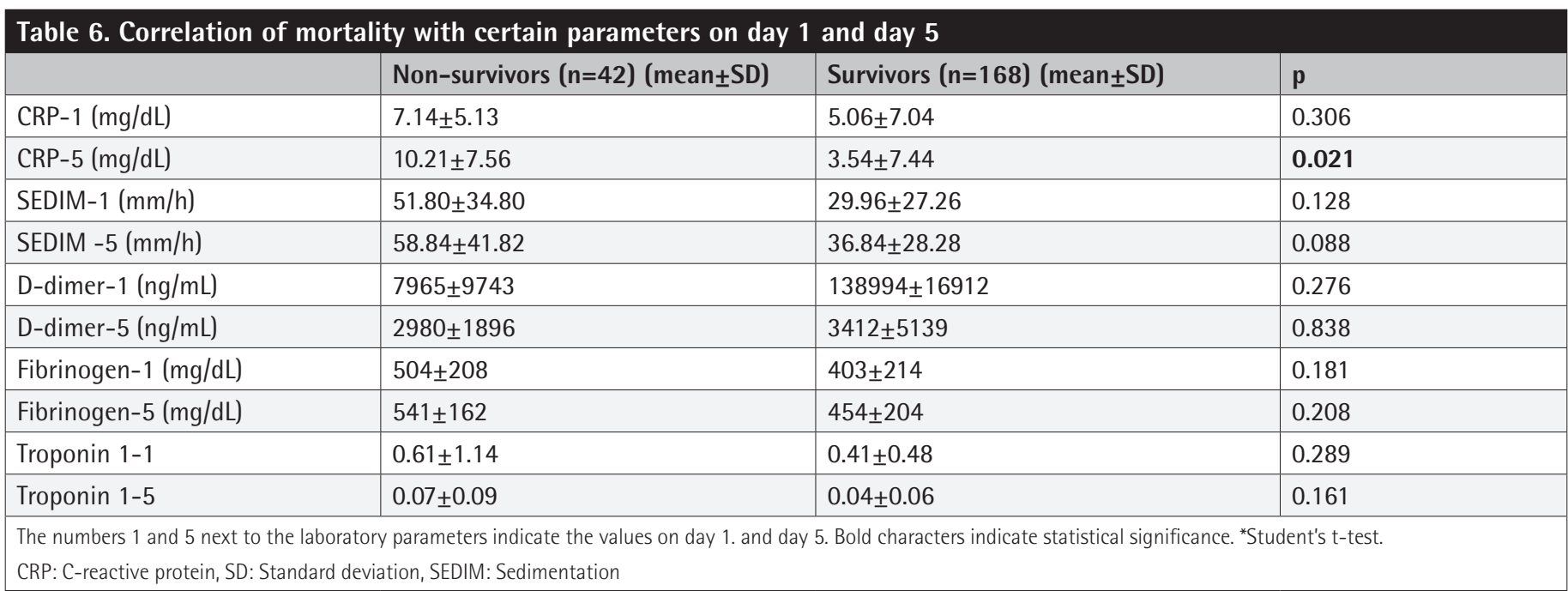

\section{DISCUSSION}

In our study, high PESI scores, low levels of hemoglobin, total protein, and albumin as checked on day 1 and day 5, high RDW levels, high ALP, and WBC, CRP and total bilirubin checked on day 5 remaining high were determined to be associated with mortality.

The incidence of pulmonary embolism is typically equal in both sexes ${ }^{4,5}$. The mortality rate of PTE in non-treated cases is approximately 30\%; however, in treated cases, the rate of mortality can decrease to below $8 \% 0^{6,7}$. Mortality typically has a linear relationship with malignancy, chronic cardiopulmonary comorbidities and advanced age $\mathrm{e}^{7,8}$.

$74 \%$ of the cases enrolled into our study were female and the incidence of PTE was found to be higher in females in this study, in contrary to the literature. Additionally, in female patients, the rate of mortality was higher although the difference was not found to be statistically significant (24.32\% and 7.69\%, respectively). In a study carried out by Obradović et al. ${ }^{9}$, which had a large population, it was reported that the mortality rate of pulmonary embolism was higher in females. The average age of the patients in our study was $71.27 \pm 13.26$ years. Although all our cases were treated, the mortality rate observed (20\%) was higher than the rate in the literature. The average age of non-survivors was higher than survivors.

While the average body temperatures of non-survivors and survivors in our study were similar, average systolic blood pressure and diastolic blood pressure levels were lower and RR values were higher. Additionally, high heartbeat per minute at arrival was correlated with mortality. The literature review did not review any studies mentioning the relevance of average heartbeat at arrival and mortality.

In many studies carried out, it has been shown that sPESI is as efficient as PESI in predicting mortality ${ }^{10-12}$. In our study, although the difference was not statistically significant, average PESI score of non-survivors weas higher, and average sPESI score was significantly higher in non-survivors. Our study also supports that sPESI score is as efficient as PESI score in determining mortality. For that reason, this score should definitely be taken into consideration in patients diagnosed with pulmonary embolism, as it is a determining factor in mortality.

When measuring ABGs, hypoxia, hypocarbia and respiratory alkalosis are expected in PTE patients. However, it can be detected as normal in $35 \%$ of the patients ${ }^{13}$. In the study carried out by Kohyama et al. ${ }^{14}$ on 207 normotensive patients diagnosed with PTE, it was shown that hypoxia was positively correlated with the weight of the patient, although it was also common in the diseases for the differential diagnosis of PTE and was not always present in patients with PTE. Our study did not reveal any significant differences between average $A B G$ values and mortality; we believe that this may be due to the fact that the sample size was small.

RDW, which is a parameter checked during routine blood tests, is a recently defined marker indicating the heterogenicity of red blood cells (anisocytosis). The increase in RDW in some cases and some studies stating that it is correlated with mortality is probably due to the fact that it increases in inflammatory conditions $^{15,16}$. In the study on 136 acute PTE patients, published by Zorlu et al. ${ }^{17}$ in 2012 , RDW $>14.6 \%$ was found to be significant in indicating mortality with a precision of $95.2 \%$ and specificity of 53\%. In the retrospective study of Zhang et al. ${ }^{18}$, which included 1,539 PTE patients, patients were divided into two groups according to the values determined with ROC analysis: RDW $>14.8 \%$ and $\leq 14.8 \%$. In the multivariate model, RDW was found to be significant in indicating mortality as an independent variable. The increase in RDW was explained more in relation to the inflammatory response mechanism against oxidative stress. In line with the literature, in our 
study, low levels of average hemoglobin on days 1 and 5 were regarded to be significantly correlated with 180-day mortality. Additionally, the average WBC on day 5 was higher in nonsurvivors and was correlated with 180-day mortality. Similarly, in our study, average RDW on days 1 and 5 was higher in nonsurvivors and this was found to be correlated with 180-day mortality, and this is also in line with the literature.

ALT and AST increases with hepatocellular damage, and bilirubin in cases of cholestasis as well as hepatocellular damage. Level of albumin and prothrombin activity are the tests that reflect the synthesis capacity of the liver ${ }^{19}$. The morbidity and mortality in hypoalbuminemic patients are higher than in patients with normal levels of serum albumin ${ }^{20}$. The increase in bilirubin is dependent on the breakdown of erythrocytes in the infarct area. Unless there is a severe problem with the liver, ALT and AST levels do not increase significantly in cases of pulmonary embolism. However, if hypoxemia is severe, these enzymes may increase depending on liver damage ${ }^{21,22}$. In our study, average levels of ALT and AST were determined to be lower in nonsurvivors both on days 1 and 5 . Despite the fact that the level of serum bilirubin was higher in non-survivors, this was not found to be correlated with mortality.

Albumin is the negative acute phase reactant. Serum levels decrease in many acute infective and inflammatory diseases. Low levels of albumin are correlated with poor prognosis and increased mortality in some diseases. The literature review has revealed studies emphasizing that low levels of serum total protein and albumin in critical diseases are correlated with mortality ${ }^{23}$. In line with the literature, our study also showed a significant decrease in average levels of serum total protein and albumin on days 1 and 5 in non-survivors.

High CRP is reported to be correlated with venous thromboembolism risk ${ }^{24}$. Our review of the literature revealed a few studies emphasizing the correlation of high CRP with prognosis of PTE. In the study conducted by Abul et al. ${ }^{25}$ on 56 patients diagnosed with acute PTE, 36-month follow-up after discharge revealed higher mortality levels in patients with high levels of CRP and troponin T. Cardiac enzymes are known to be specific and sensitive markers indicating myocardium damage, released from the myocardium due to the overload on the right ventricle, reflecting left ventricle dysfunction. The mortality levels of patients, whose troponin levels were determined to be high in several meta-analyses, were significantly higher than patients with normal troponin levels ${ }^{26}$. Although the average level of CRP was higher in non-survivors on day 1 , it was not significantly correlated with mortality; however, the high levels of CRP on day 5 were correlated with mortality, in line with the literature. Additionally, in contrary to the literature, no significant correlation was detected between average level of serum troponin T on days 1 and 5 and mortality.

\section{Study Limitations}

There are some limitations of this study that should be mentioned. The first limitation is that the data are based on hospital records since it is a retrospective study; and the second limitation may be that patients do not have longer followup. Another limitation is that the study may not reflect the general population due to the low number of patients included in the study.

\section{CONCLUSION}

In conclusion, PTE is a disease with high mortality and morbidity despite the advances in diagnosis and treatment. Routine, easily applicable physical examination and laboratory findings may help in predicting mortality.

\section{Ethics}

Ethics Committee Approval: The study were approved by the Bezmialem Vakıf University Non-Invasive Ethics Committee (decision number: 03/20, date: 05.02.2020).

Informed Consent: Consent form was filled out by all participants.

Peer-review: Externally peer-reviewed.

\section{Authorship Contributions}

Surgical and Medical Practices: H.Ç., G.I.D., Concept: H.Ç., Design: G.I.D., Data Collection or Processing: H.Ç., G.I.D., Analysis or Interpretation: H.Ç., Literature Search: G.I.D., Writing: H.Ç.

Conflict of Interest: No conflict of interest was declared by the authors.

Financial Disclosure: The authors declared that this study received no financial support.

\section{References}

1. Koupenova M, Kehrel BE, Corkrey HA, Freedman JE. Thrombosis and platelets: an update. Eur Heart J. 2017;38:785-91.

2. Suwanabol PA, Hoch JR. Venous thromboembolic disease. Surg Clin North Am. 2013;93:983-95.

3. Zöller B, Li X, Ohlsson H, Ji J, Memon AA, Svensson PJ, et al. Epidemiology of Familial Aggregation of Venous Thromboembolism. Semin Thromb Hemost. 2016;42:821-32.

4. Tormene D, Ferri V, Carraro S, Simioni P. Gender and the risk of venous thromboembolism. Semin Thromb Hemost. 2011;37:193-8.

5. EINSTEIN-PE Investigators, Büller HR, Prins MH, Lensin AW, Decousus $H$, Jacobson $B F$, et al. Oral rivaroxaban for the treatment of symptomatic pulmonary embolism. N Engl J Med. 2012;366:1287-97.

6. Keller K, Beule J, Balzer J0, Dippold W. Evaluation of Risk Stratification Markers and Models in Acute Pulmonary Embolism: Rationale and Design of the MARS-PE (Mainz Retrospective Study of Pulmonary Embolism) Study Programme. Acta Medica (Hradec Kralove). 2018;61:93-7. 
7. Nijkeuter M, Söhne M, Tick LW, Kamphuisen PW, Kramer MH, Laterveer L, et al. The natural course of hemodynamically stable pulmonary embolism: Clinical outcome and risk factors in a large prospective cohort study. Chest. 2007;131:517-23.

8. British Thoracic Society Standards of Care Committee Pulmonary Embolism Guideline Development Group. British Thoracic Society guidelines for the management of suspected acute pulmonary embolism. Thorax. 2003;58:470-83.

9. Obradović S, Džudović B, Rusović S, Subota V, Obradović D. Gender-related differences in clinical presentation, electrocardiography signs, laboratory markers and outcome in patients with acute pulmonary embolism. Vojnosanit Pregl. 2016;73:844-9.

10. Klok FA, Dzikowska-Diduch 0 , Kostrubiec M, Vliegen HW, Pruszczyk $P$, Hasenfuß G, et al. Derivation of a clinical prediction score for chronic thromboembolic pulmonary hypertension after acute pulmonary embolism. J Thromb Haemost. 2016;14:121-8.

11. Jiménez D, Aujesky D, Moores L, Gómez V, Lobo JL, Uresandi F, et al. Simplification of the pulmonary embolism severity index for prognostication in patients with acute symptomatic pulmonary embolism. Arch Intern Med. 2010;170:1383-9.

12. Tamizifar B, Fereyduni F, Esfahani MA, Kheyri S. Comparing three clinical prediction rules for primarily predicting the 30-day mortality of patients with pulmonary embolism: The "Simplified Revised Geneva Score," the "Original PESI," and the "Simplified PESI". Adv Biomed Res. 2016;5:137.

13. Squizzato A, Dentali F, Steidl L, Ageno W. New direct thrombin inhibitors. Intern Emerg Med. 2009;4:479-84.

14. Kohyama $T$, Moriyama $K$, Kanai $R$, Kotani $M$, Uzawa $K$, Satoh $T$, et al. Accuracy of pulse oximeters in detecting hypoxemia in patients with chronic thromboembolic pulmonary hypertension [published correction appears in PLoS One. 2015;10: e0141944.

15. Dabbah S, Hammerman H, Markiewicz W, Aronson D. Relation between red cell distribution width and clinical outcomes after acute myocardial infarction. Am J Cardiol. 2010;105:312-7.
16. Rhodes CJ, Wharton J, Howard LS, Gibbs JS, Wilkins MR. Red cell distribution width outperforms other potential circulating biomarkers in predicting survival in idiopathic pulmonary arterial hypertension. Heart. 2011;97:1054-60.

17. Zorlu A, Bektasoglu G, Guven FM, Dogan OT, Gucuk E, Ege MR, et al. Usefulness of admission red cell distribution width as a predictor of early mortality in patients with acute pulmonary embolism. Am J Cardiol. 2012;109:128-34.

18. Zhang $\mathrm{Z}, \mathrm{Xu} \mathrm{X}, \mathrm{Ni} \mathrm{H}$, Deng $\mathrm{H}$. Red cell distribution width is associated with hospital mortality in unselected critically ill patients. J Thorac Dis. 2013;5:730-6.

19. Gyamlani G, Molnar MZ, Lu JL, Sumida K, Kalantar-Zadeh K, Kovesdy CP. Association of serum albumin level and venous thromboembolic events in a large cohort of patients with nephrotic syndrome. Nephrol Dial Transplant. 2017;32:157-64

20. Massicotte-Azarniouch D, Bader Eddeen A, Lazo-Langner A, Molnar AO, Lam NN, McCallum MK, et al. Risk of Venous Thromboembolism in Patients by Albuminuria and Estimated GFR. Am J Kidney Dis. 2017;70:826-33.

21. Newland CD. Acute Liver Failure. Pediatr Ann. 2016;45:e433-e8.

22. Middleton JR, Chigerwe M, Fine DM, Turk JR, Lattimer JC. Pulmonary hypertension and right-sided heart failure in an adult llama with hepatic disease. J Am Vet Med Assoc. 2006;228:756-9.

23. Omar HR, Mirsaeidi M, Rashad R, Hassaballa H, Enten $G$, Helal $E$, et al. Association of Serum Albumin and Severity of Pulmonary Embolism. Medicina (Kaunas). 2020;56:26.

24. Zacho J, Tybjaerg-Hansen A, Nordestgaard BG. C-reactive protein and risk of venous thromboembolism in the general population. Arterioscler Thromb Vasc Biol. 2010;30:1672-8.

25. Abul Y, Karakurt S, Ozben B, Toprak A, Celikel T. C-reactive protein in acute pulmonary embolism. J Investig Med. 2011;59:8-14.

26. Becattini C, Vedovati MC, Agnelli G. Prognostic value of troponins in acute pulmonary embolism: a meta-analysis. Circulation. 2007;116:427-33. 